Fjałkowski K., Politicians and social leaders. Introducing a model of mutual relations and shaping beliefs of voters, „Ekonomia i Prawo. Economics and Law.”, Polszakiewicz B., Boehlke J. (ed.), Vol. 13, No. 3/2014, pp. 359-375. DOI: http://dx.doi.org/10.12775/EiP.2014.026.

\title{
POLITICIANS AND SOCIAL LEADERS. INTRODUCING A MODEL OF MUTUAL RELATIONS AND SHAPING BELIEFS OF VOTERS
}

\author{
SUMMARY
}

This paper introduces an informal model of behavior of Politicians and Social Leaders in their mutual relations in the context of influencing the beliefs of voters. Facing uncertainty about Politicians voters turn to Social Leaders as information short-cuts. Leaders include NGOs, the media and religious organizations. The Politicians-Leaders relations are modeled as complex implicit Principal-Agent contracts. The model predicts various forms of opportunistic behavior of both sides. Numerous behavioral predictions of the model as well as empirical examples from contemporary Polish socio-political life have been provided.

Keywords: public choice, voting, media, religion, opportunism

JEL Classification: D72, D86, L82, Z12

\section{INTRODUCTION}

Public choice theory describes the behavior of politicians and other actors of political and social life. Most of the research in the field so far seems to

* Karol Fjałkowski, Wroclaw University of Economics, Faculty of Economic Sciences, Department of Microeconomics and Institutional Economics, ul. Komandorska 118/120, 53-345 Wrocław, phone: +48 713680 196, e-mail: karol.fjalkowski@ue.wroc.pl. 
have been focused mainly on politicians, interest groups and voters pursuing their private interests under various institutional settings. However, in contemporary complex representative democracies, voters, if they vote at all, find themselves unable to collect by themselves and process all information necessary to select political choices most compatible with their preferences. Therefore they turn to intermediaries for information and guidance in the sociopolitical arena. As John R. Zeller put it, "to the extent that few like but none can avoid, citizens in large societies are dependent upon (...) others for most of their information about the larger world in which they live"1. This of course pertains also to acquiring knowledge about the political process and its participants.

As early as A. Downs's fundamental "Economic Theory of Democracy" of 1957 there has been a recognition of the major role in politics of these individuals and organizations whose services are used by voters to learn about political options, or these who can otherwise influence voters to act in a particular way. Downs dubbed these subjects first "persuaders" ${ }^{2}$ and then "leaders" . According to T. Michalak, the Downsian list of political leaders includes political parties themselves, interest groups, and "favor-buyers", such as the media ${ }^{4}$. Slight amendment of this list seems in place because social and political leaders include also individuals or organizations which are normally occupied in other areas of life, such as literature, science, religion, charity etc. Therefore, in this paper social Leaders in question will be understood to include: the media and individual journalists, bloggers, scientists, NGOs and their charismatic leaders, religious organizations and their charismatic leaders, and generally organizations and individuals with widely-shared factual credibility or moral authority.

They do not have any formal political power, however in being able to shape beliefs and choices of people, they possess some "government of the souls" (pol. rząd dusz) to use A. Mickiewicz's phrase. This soft power par excellence, cannot be overlooked by Politicians, which in turn are understood to be individuals or organizations striving to acquire and maintain strictly political power. The electoral success of Politicians is dependent upon whether and how exactly voters are informed about them and their opponents. If Pol-

${ }^{1}$ J.R. Zaller, The Nature and Origins of Mass Opinion, Cambridge University Press, 1992, p. 6.

2 A. Downs, An Economic Theory of Political Action in a Democracy, "Journal of Political Economy", Vol. 65, No. 2/1957, p. 139.

3 A. Downs, An Economic Theory of Democracy, Harper \& Row, New York 1957, p. 87, according to: T. Michalak, Ekonomiczna teoria demokracji Anthony'ego Downsa, [in:] J. Wilkin (ed.), Teoria wyboru publicznego, Wydawnictwo Scholar, Warszawa 2005, p. 76.

${ }^{4}$ T. Michalak, op. cit., p. 76. 
iticians literary have "bad press" they may not be appreciated by voters however committed and hard-working they are. Conversely, winning the favors of Leaders may help cover-up or misrepresent actually opportunistic behavior of the Politician relative to his or her challengers, and therefore increase the odds of (re)election. Also Leaders, just like any other individuals or interest groups, may benefit greatly from relations with the government in many ways, ranging from direct monetary transfers to favorable sophisticated modifications in the legal environment of their ordinary operations. Additionally, taking into account the growing dependency of voters on Leader-provided information, it is somewhat surprising how relatively little effort so far has been devoted to modeling and explaining the relations between Politicians and Leaders. Filling this gap meaningfully is the aim of this paper.

Downs assumed exogenously given voters' preferences, which has been criticized $^{5}$ and numerous attempts have been made at endogenizing the processes of shaping the preferences of voters ${ }^{6}$. Politicians do a great deal to self-advertise, however it needs to be acknowledged that self-advertising by Politicians lacks credibility. The Politician's electoral communication is obviously favorably biased, and save for efficiency of manipulation techniques used, it cannot be considered by an undecided voter as a source of reliable information about the Politician's credentials. Hence the demand of Politicians for third-party endorsement.

However, Leaders face the problem of credibility also. Being an explicit persuader ruins the effectiveness of persuasion. Experience of living in a democracy suggests, that direct payments from a Politician to a newspaper or a scientist would damage its reputation as provider of unbiased information, and ipso facto would damage the value of the Leader to the Politician, since this Leader is no longer able to attract any voters. Even the slightest evidence of being politically involved or financed by a Politician of media broadcasters, scientists, religious organizations etc. is actively traced down and exposed by rival Leaders. The issue of credibility seems key to understanding the behavior of Leaders. Furthermore, it is both interesting and necessary to note that in modern democracy, the corporate existence and operations of many Leaders are much more durable than that of the Politicians.

${ }^{5}$ See P. Dunleavy, H. Ward, Exogenous Voter Preferences and Parties with State Power: Some Internal Problems of Economic Theories of Party Competition, „British Journal of Political Science”, Vol. 11/1981, p. 351-380.

${ }^{6}$ See for example J.E. Jackson, Electoral Competition with Endogenous Voter Preferences, Unpublished paper prepared for the Annual Meeting of the Midwest Political Science Association, Chicago, April 19, 1996, with an extensive review of literature on the subject. 
Such Leaders must adopt a strategy of survival and pursuit of its interests under changing incumbent Politicians. Therefore, again, a rather balanced communication is to be expected of Leaders in whose long-term interest is to accommodate to many different possible political circumstances.

This paper proposes a model of behavior of Politicians and Leaders in their mutual relations in the context of shaping beliefs of voters. Also provided is a preliminary empirical investigation of facts from contemporary Polish political and social life. The model could be interpreted as an extension of the Down's model in one of its detailed aspects. All standard theoretical background of public choice theories is assumed, most notably the description of relations between voters and politicians as the Principal-Agent relationship. Also, Williamson's understanding of opportunism and its consequences apply. Both Politicians and Leaders are assumed to "maximize at every margin", to use D.C. North's term, which means opportunistic behavior whenever marginally beneficial.

The paper is organized as follows. Chapter 1 includes a brief survey of literature on the role of Leaders in competitive politics. Although the author holds the Friedmanite position on the subject of the role of assumptions in economic modeling, special emphasis is put on supporting the assumptions of the proposed model as indeed "realistic". In Chapter 2 the proper model of Politicians - Leaders relations is presented. Assumption as well as propositions of the model are put forward. What follows in Chapter 3 is a preliminary survey of empirical facts from Polish socio-economic life with regard to their conformity with the predictions of the model. Some final thoughts and comments on future research are given in Conclusions.

\section{SOCIAL LEADERS AND COMPETITIVE POLITICS. A BRIEF SURVEY OF LITERATURE}

\subsection{VOTER UNCERTAINTY AND LEADERS AS SHORT-CUTS TO INFORMATION}

The general logic recognized in the literature for the existence and significance of Leaders is as follows. The voter is assumed to operate in the political realm under pervasive uncertainty. Downs himself concluded that because relevant information gathering is so marginally costly relative to marginal benefits of voting, therefore it would be "rational" for any individual voter to stay ignorant and not bother voting at all ${ }^{7}$. Contrary to that prediction, consid-

7 A. Downs, An Economic Theory of Democracy, op. cit., p. 219, according to: T. Michalak, op. cit., p. 79. 
erable numbers of people do vote. For this "turnout paradox" there has been proposed a solution. It is assumed that instead of gathering all necessary information, people use information short-cuts ${ }^{8}$ and engage in "low-information rationality" - practical reasoning about politics based on combining information from different low-cost sources - "daily life, the media" etc9.

Thus uncertainty makes potential voters frequent recipients of political communication from Leaders. However, even under this "low-cost" rationality information gathering still is selective on the basis of the perceived credibility of the information and its source. According to a classic study by C.I. Hovland, I.L. Janis and H.H. Kelley, important factors influencing the effectiveness of persuasive communication include perceived cues about the source's "trustworthiness, intentions and affiliations" ${ }^{10}$. Persuasiveness is reduced by perceived reporting bias of the source, that could be defined after A.H. Eagly, W. Wood and Sh. Chaiken as "belief that a communicator's willingness to convey an accurate version of external reality is compromised"11. In other words, voters judge a Leader to be biased and unreliable to the extent that they perceive dependencies of the Leader on a particular Politician for financial, personal, legal, or other kinds of gains. The "low-information rationality" voters seem to reason consistently that if a Leader is for example financed by a particular Politician, the Leader is disqualified as a reliable authority on political matters.

Perhaps a branch of public choice study most akin to this one are attempts at models of the role of interest groups in electoral competition with voters under uncertainty. Interest groups are assumed there to provide Politicians with services complimentary to that of Leaders, mainly campaign contributions and some endorsement, in exchange for rent-seeking opportunities $^{12}$. B. Grofman and B. Norrander give a model of choice that a vot-

${ }^{8}$ B. Grofman, Introduction, [in:] B. Grofman (ed.), Information, Participation, and Choice: An Economic Theory of Democracy in Perspective, University of Michigan Press 1995, p. 5.

9 S.L. Popkin, The Reasoning Voter: Communication and Persuasion in Presidential Campaigns, University of Chicago Press 1994, p. 44n.

${ }^{10}$ C.I. Hovland, I.L. Janis, H.H. Kelley, Communication and persuasion: psychological studies of opinion change, Greenwood Press 1953, p. 13.

11 A.H. Eagly, W. Wood, Sh. Chaiken, Causal inferences about communicators and their effect on opinion change, "Journal of Personality and Social Psychology”, Vol. 36, 4/1978, p. 424.

12 See foremost: D.P. Baron, Electoral Competition with Informed and Uninformed Voters, „American Political Science Review”, Vol. 88, No. 1/1994, p. 33-47 and G.M. Grossman, E. Helpman, Protection for Sale, „The American Economic Review”, Vol. 84, No. 4/1994, p. 833-850; T. Wegenast, Uninformed Voters for Sale: Electoral Competition, Information and Interest Groups in the US, „Kyklos”, Vol. 63, No. 2/2010, p. 271-300. 
er makes between two endorsers of this kind ${ }^{13}$. One work of G.M. Grossman and E. Helpman is especially important for this study ${ }^{14}$. The authors analyze a situation in which a leader of an organized interest group, such as a trade union, is a Leader influencing voting behavior of the members of this group. Findings suggest that Politicians compete for endorsement from such a Leader if this intra-group persuasion is "not readily observable" to outsiders of the group. Importantly, as the authors state, competing for endorsement of such a Leader means "favoring special interest of this group at the expense of unaffiliated voters" 15 .

\subsection{THE MEDIA AND THE CLERGY AS SOCIAL LEADERS}

As mentioned above, the media are a very convenient information "shortcuts" for "low-cost rationality" voters. Demonstrations that voters actually use the media as sources of information about Politicians are abundant. S. DellaVigna and E. Kaplan report that the even a mere introduction of Fox News into cable networks in the United Stated between 1996 and 2000 was able to make a statistically significant impact of voting behavior ${ }^{16}$. In the context of this paper, especially worth mentioning seem these studies that show how media coverage can help "forget" or "remember" behavior of Politician. For example, it seems that generally corruption scandals and other misbehavior of Politicians is indeed soon "forgotten" by voters. This effect however is the weaker, the more a scandal receives media coverage and the more a voter is attentive to the media ${ }^{17}$.

On the other hand, the media are potentially rent-seeking businesses and interest groups themselves. Moreover, they are the ones that are in control of the flow of information. This creates vast opportunities for special interests mutual bargaining with Politicians. For example, M. Petrova provides "Political Economy of Media Capture" with some quantitative analysis of the phe-

13 B. Grofman, B. Norrander, Efficient use of reference group cues in a single dimension, „Public Choice", No. 64/1990, p. 213-227.

${ }^{14}$ G.M. Grossman, E. Helpman, Competing for Endorsements, „The American Economic Review", Vol. 89, No. 3/1999, p. 501-524.

15 Ibidem, p. 517.

16 S. DellaVigna, E. Kaplan, The Fox Nerws Effect: Media Bias and Voting, „The Quarterly Journal of Economics", Vol. 122, No. 3/2007, p. 1187-1234.

${ }^{17}$ M. Klasnja, Why Do Malfeasant Politicians Maintain Political Support? Testing the "Uninformed Voter" Argument, Unpublished Draft, August 2011; A. Sole-Olle, P. Sorribas-Navarro, Do Corruption Scandals Erode Trust in Government? Evidence from a Matched Sample of Local Governments, Unpublished paper prepared for the CESifo Area Conference on Public Sector Economics, Munich, 24-26 April 2014. 
nomenon ${ }^{18}$. Results show that incumbent Politicians influence the media to affect public opinion, which distorts political competition, and adversely affects equality, provision of public goods, and other public policy variables. Media capture seems weaker where there is a developed advertising market, which provides alternative, independent source of funding ${ }^{19}$.

A distant yet noble and important predecessor of the analysis presented in this paper is Adam Smith's study of Church - State relations, to which topic he devotes a special chapter in the "Wealth of Nations". Among other issues discussed, Smith laments the entanglement of interest of particular political factions with particular religious organizations and he blames this state of affairs for antagonisms between different religions ${ }^{20}$. Also A. Gill's book on "The Political Origins of Religious Liberty" is ultimately an analysis of a Politicians - Leaders kind of relations that are the subject of this paper. This author clearly depicts the implicit, and occasionally explicit, deals possible between incumbent Politicians and religious Leaders - legitimization and ideological support in exchange for transfers and favorable regulation, up to the point of establishing a religious monopoly ${ }^{21}$.

Vast literature exists on the topic of the impact of Religion in American politics, which exceeds the subject of this paper. Political communication of clergy remains within the scope of interest of this study, of which an exhaustive literature overview is given in M. Woolfalk's yet unpublished paper, very aptly entitled "Sermons Aren't Explicitly Political"22. As T.G. Jelen points out, "Clergy undoubtedly have the capacity to shape the political beliefs, attitudes and skill of their congregations (...) therefore the extent, style and motivation of political activism among clergy have important implications for the practice of democratic politics"23.

${ }_{18}$ M. Petrova, Political Economy of Media Capture, [in:] R. Islam (ed.), Information and Public Choice. From Media Markets to Policy Making, The World Bank, Washington 2008.

19 Ibidem, p. 135.

20 A. Smith, Badania nad natura i przyczynami bogactwa narodów, PWN, Warszawa 1954, p. 530-568.

21 A. Gill, The Political Origins of Religious Liberty, Cambridge University Press 2008. See especially Chapter 1 subsections "Negative Subsections of Religious Liberty" and "Positive Endorsement of Specific Denominations".

22 M. Woolfolk, Sermons Aren't Explicitly Political: Political Cue-Giving in Sermons by U.S. Christian Clergy, Unpublished Working Paper May $9^{\text {th }} 2013$.

${ }_{23}$ T.D. Jelen, Notes for a Theory of Clergy as Political Leaders, [in:] S.E.S. Crawford, L.R. Olson (eds.), Christian Clergy in American Politics, JHU Press 2003. 


\section{THE MODEL OF BEHAVIOR OF POLITICIANS AND SOCIAL LEADERS IN MUTUAL RELATIONS}

\subsection{ASSUMPTIONS}

a. The political system is a majority-rule stable democracy. Elections take place regularly and result either in the re-election of the Incumbent or its replacement by the Challenger.

b. There are two Politicians: an Incumbent and a Challenger. The difference is that the Incumbent actually possesses discretionary power to produce or reduce welfare of voters and provide or revoke benefits to Leaders in the form of transfers and regulations. The expected utility of a Politician is a function of benefits of gaining and maintaining power minus costs of gaining and maintaining power.

c. Voters embrace a large, diverse society. Voter's preferences are exogenously given.

d. There are two Leaders. The Leader's main resource is his or her Credibility. Credibility is understood as the degree to which it is believed by voters to be a trustworthy and unbiased reporter of Politicians' performance, competence and political integrity. Because of Credibility, Leaders can increase or decrease utility of Politicians by communication effectively encouraging or discouraging voters from voting in a particular way. The expected utility of a Leader is a function of transfers and rents acquired due to decisions of Politicians.

e. Leaders' soft power of influence over the situations of Politicians is a function of Credibility.

f. Credibility is a function of the voters not perceiving any cues or evidence of benefits or promises from Politicians to the Leader. It is reduced every time such perception occurs.

g. All subject are potentially opportunistic utility-maximizers.

h. Ideological premises of all subjects are similar, ambiguous or otherwise their importance as constraints for utility maximization is consider negligibly small.

i. Voter - Incumbent relation is an explicit Principal-Agent relationship. The welfare of the voters is a function of Incumbent's competence, political integrity and a stochastic factor. A vast information asymmetry between voters and Politicians exists and voters remain under uncertainty as to actions as well as competence and political integrity of all Politicians.

j. Incumbent - Leader relation is an implicit Principal-Agent relationship. Because of information asymmetry, the Incumbent can always cla- 
im to the Leader benefits are revoked because of objective budgetary constraints, the sake of public interest etc. Similarly, because of information asymmetry, the Leader can always claim to the Incumbent that favorable communication is less explicit than expected because of objective strategic requirements for maintaining Credibility.

\subsection{PROPOSITIONS}

a. Until his or her private marginal benefits equal marginal costs, the Incumbent will deprive voters of a portion of welfare and direct benefits to Leaders in order to acquire their favors (and Challenger will promise to do so).

b. The Incumbent must choose such ways of providing benefits for the Leaders so as not to damage their Credibility. Benefits of transfers and regulation must not be "readily observable". They must take covert and unusual forms, or else scrutiny by unfavorable Leader reduces the Credibility of the favorable Leader and therefore renders him or her unpersuasive to the voters. For example, the Politician can pass a slight (for example: a two-word) modification in a regulation, which would seem insignificant, but in fact will yield to the Leader much rent.

c. The long-term utility-maximizing strategy of the Incumbent is not to favor one particular Leader; rather it will involve using discretionary power over directing rents in such a way, so as to maximize net gains from favorable communication from all the Leaders.

d. Given a Leader has been "locked-in" into an implicit contract, for example he or she is now planning its long-term budget taking government subsidies for granted, a utility-maximizing Incumbent will introduce and maintain a constant and credible threat of revoking the benefits if favorable results on the part of the Leader are not satisfactory. The Incumbent may take some short-term retaliatory actions against unfavorable Leaders, to increase credibility of such threat.

e. Leaders will not engage in explicit propaganda in favor of a particular Politician because of the following reasons: 1) Connections with a Politician will be investigated and exposed by the rival Leader, 2) It could result in a huge loss of Credibility to make substantive twists of opinion if (for some exogenous reason) the Incumbent loses next elections and is replaced by current Challenger, 3) If the Incumbent loses next elections and the Challenger takes his place, he or she may take retaliatory actions against Leaders who have been unfavorable to him or her, 4) It may disco- 
urage the Challenger from competitive bidding and so reduce the benefits acquired from the Incumbent.

f. A utility-maximizing Leader must choose vague and ambiguous language, and only occasionally endorse the favored Politician, and still in ways not readily recognizable as such, in order to avoid threats given above. For example, rather than openly acclaim a Politician, the Leader can promote as pressing and bearing heavily on the welfare of voters those problems which the Politician holds prominent in his or her agenda.

g. Ambiguous positions of a Leader induce both Incumbent and Challenger to participate in competitive bidding for the favors of this Leader.

h. The long-term utility-maximizing strategy of a Leader is not to be a Dowsian persuader for one particular Politician; rather it is to highlight Credibility so as to induce both Incumbent and Challenger to competitively bid for its favors with benefits and promises.

The model yields very numerous predictions about the behavior of Politicians and Leaders in their mutual relations. Also the media coverage of current events is very rich. Due to space limitations in the next section only some of behavioral predictions of the model are listed, supported with examples of observable events, whose occurrence, and occasionally even details, are consistent and explicable with the proposed model.

\section{PRELIMINARY EMPIRICAL VALIDATION OF THE MODEL - EXAMPLES FROM POLISH SOCIO-POLITICAL LIFE}

Tools for reducing rival or unfavorable Leaders' Credibility include accusations of "politicization" as well as "pro-government" and "pro-Party-X" labels. But more than merely issuing accusations, Leaders actively seek and expose "evidence" of "politicization" of rival Leaders. For example, in 2012 Jerzy Owsiak, a charity and youth activist, invited incumbent president Bronisław Komorowski to the music festival organized by him annually ${ }^{24}$. In 2013 a huge logo of Owsiak's charitable action has been displayed on the façade of the Presidential Palace and the president endorsed taking part in the action ${ }^{25}$. These events were explicitly commented in conservative press as evidence

${ }^{24}$ wPolityce.pl, Woodstock - festiwal konserwujacy III RP, http://wpolityce.pl/wydarzenia/32624-woodstock-festiwal-konserwujacy-iii-rp-goscmi-owsiaka-beda-min-prezydent-komorowski-redaktor-paradowska-oraz-bp-pieronek (29.11.2013).

${ }^{25}$ Wyborcza.pl, Prezydent zagrat z Owsiakiem już w sobote, http://wyborcza. pl/1,76842,13188298,Prezydent_zagral_z_Owsiakiem_juz_w_sobote.html (30.11.2013). 
of connections between J. Owsiak and particular Politicians. When Lech Kaczyński was president in 2009, Owsiak refused to invite him to Przystanek Woodstock ${ }^{26}$.

More recently, in 2013 "Gazeta Wyborcza" publicized a report of official political parties' expenditures ${ }^{27}$. Politicians had the hardest time during interviews to explain why well-known journalists and social scientists appeared on their payrolls ${ }^{28}$. A detailed analysis was conducted by rival journalists of a relation between Radio "Wnet" being financed by an opposition party $\mathrm{PiS}$ and favoritism shown by Wnet's director towards that party ${ }^{29}$. Later that year "Gazeta Polska” began in turn to scrutinize the flow of announcements from the governmental Martial Property Agency to "Gazeta Wyborcza". It was highlighted that even local real estate auctions were announced on whole pages of the national edition of "Gazeta Wyborcza" 30 and it was "exposed" as covert transfers being in fact rewards from the government for "Wyborcza"s favoritism"31.

Both Leaders and Politicians seem to engage in signaling willingness to cooperate. For example, almost all politicians pronounce verbal declarations about the importance of the Catholic Church in Polish socio-economic life. President Komorowski stated publicly he views the Church as "an important element in the civil society"32, but opposition party leader Jarosław Kaczyński declared in 2013 that the Church is so central to the moral identity of the Poles, that "whoever attacks the Church, attacks Poland"33. In turn, in 2008 the president of the Conference of Polish Bishops, Józef Glemp, took his time

${ }^{26}$ G. Górny, Czego uczy nas Jerzy Owsiak, http://www.wsieci.p1/czego-uczy-nas-jerzy-owsiak-pnews-245.html (30.11.2013).

27 A. Nowakowska, D. Wielowieyska, Jak PiS i PO wydaja miliony z budżetu, http://wyborcza.pl/politykaekstra/1,133134,14083575,Jak_PiS_i_PO_wydaja_miliony_z_budzetu.html (30.11.2013).

${ }^{28}$ Gazeta.pl, PiS ptacito radiu Skowrońskiego i Lux Veritatis, http://www.tokfm.pl/ Tokfm/1,103087,14085943,PiS_placilo_radiu_Skowronskiego_i_Lux_Veritatis_Kaminski_. html (1.12.2013).

${ }^{29}$ K. Lepczyński, Dtuga droga Skowrońskiego. Od radiowej grwiazdy do „konferansjera PiS”, http://www.tokfm.p1/Tokfm/1,103088,14088108,Dluga_droga_Skowronskiego_Od_radiowej_ gwiazdy_do.html (29.11.2013).

30 Youtube.pl, Chtodnym okiem - Bronistaw Wildstein o reklamie w Gazecie Wyborczej, http:// www.youtube.com/watch?v=w3uuGoqeaf0 (1.12.2013).

${ }^{31}$ W. Kamiński, Rzqdowe miliony dla „Wyborczej”, http://gpcodziennie.pl/24252-rzadowe-miliony-dla-wyborczej.html (1.12.2013).

${ }^{32}$ Fonda.pl, Prezydent Komorowski: Kościót to ważny element spoteczeñstwa, http://www.fronda. $\mathrm{pl} /$ a/prezydent-komorowski-kosciol-to-wazny-element-spoleczenstwa,31237.html (1.12.2013).

${ }_{33}$ TVP.info, „Kto atakuje Kościót, ten atakuje Polskę”, http://tvp.info/informacje/polska/kto-atakuje-kosciol-ten-atakuje-polske/6765592 (1.12.2013). 
during his Christmas Eve television speech to admonish the faithful for praying too little for incumbent politicians "who perform their tasks in the spirit of service and responsibility" 34 .

As predicted by the model, transfers from Politicians to Leaders must take covert and unusual forms in order not to be identified as benefits. In 2014, the government prepared a short film about the 10th anniversary of Poland joining the European Union ${ }^{35}$. The film's cost of production and displaying in television and Internet was commonly held as so high, that media producers wondered how so much money could be spent. These seemingly puzzling events took place in the middle of the European Parliament election campaign and it involved millions of zlotys transferred as ordinary purchase of advertising time in the media.

Most Leaders, on the other hand, do not openly support particular Politicians, even when they are expected or asked to do so. For example, representatives of the Catholic Church in Poland often remind the faithful about the "civil duty" to vote and the very general principles of Catholic Social Teaching. However, they consistently evade indicating who exactly a Catholic should vote for. For example, in their Message before 2007 general elections Polish bishops wished "to remind once more that the Church does not have any political representation, and so no political party has the right to speak on behalf of the Church or claim its support (...) Pastors should not be engaged in political campaigning on any side. The same principle applies also to Catholic media" ${ }^{36}$.

At the same time, according to calculations of Money.pl based on government data, the Catholic Church in Poland relies mostly not on the faithful, but on the government for income, which takes different forms, including subsistence of historic church buildings, school and pre-school catechesis, Theology departments of state-run universities, army and hospital chaplains etc. ${ }^{37}$. Any withdrawal of one of these specific sources of funding by the government would be at least troublesome for the Church, which reflects the "lock-in" ef-

${ }^{34}$ TVP.info, Orędzie prymasa Glempa na Boże Narodzenie, http://tvp.info/magazyn/kartka-z-kalendarza/oredzie-prymasa-glempa-na-boze-narodzenie/9856914 (30.11.2013).

35 Dziennik.pl, 7 mln zt za rzqdowy spot. „Niech PO wpisze to w koszty kampanii”, http://wiadomosci.dziennik.pl/polityka/artykuly/456827,pis-o-rzadowym-spocie-za-7-mln-zl-niech-po-wpisze-to-w-koszty-kampanii.html (1.12.2013).

${ }_{36}$ Episkopat.pl, Odpowiedzialność za dobro wspólne, http://episkopat.pl/dokumenty/listy_paste rskie/4486.1,Odpowiedzialnosc_za_dobro_wspolne.html (1.12.2013).

37 A. Zwoliński, Fundusz Kościelny to nic. Zobacz, ile kosztuje nas konkordat, http://www.money.pl/gospodarka/raporty/artykul/fundusz;koscielny;to;nic;zobacz;ile;kosztuje;nas;konkord at, 17,0,1046545.html (1.12.2013). 
fect in incomplete contracts described by O.E. Williamson ${ }^{38}$. In such a situation, by holding the Leader in a protracted suspension with regard to future funding, the Politician can hope to extract from him or her some extra favors. In 2011 prime minister Donald Tusk announced plans for a reform the Church Fund, which mainly finances priests' pension insurance ${ }^{39}$. It was supposed to be replaced by a defined percent of income tax able to be redirected to the Church by the faithful. Negotiations started between government and Church officials about what exactly this percent will amount to as well as other details. Successful end to the negotiations has been announced several times ${ }^{40}$ but as of October 2014, near the end of the political term, new supposed difficulties still emerge and block reaching a final agreement ${ }^{41}$. It is worth noting however, that government expenditures for the Church Fund in 2015 are "unexpectedly" scheduled to increase ${ }^{42}$. In 2015 both general and presidential elections are going to be held, and the announcement itself about the expansion of state financing for the Church Fund came less than a month before local elections of November 2014.

In a similar fashion, the list of periodicals subsidized by the Ministry of Culture is frequently revised ${ }^{43}$. As a consequence, almost every year many socio-cultural periodicals relying heavily on this subsidy, must put a lot of effort to stay on list, as the threat of falling out is real ${ }^{44}$.

38 See A. Nicita, U. Pagano, Incomplete contracts and institutions, [in:] J.G. Backhaus (ed.), The Elgar Companion to Law and Economics, Edward Elgar 2005, p. 146.

39 PAP, Będzie likwidacja Funduszu Kościelnego?, http://www.tvp.info/5463535/informacje/polska/bedzie-likwidacja-funduszu-koscielnego/ (1.12.2013).

${ }^{40}$ GazetaPrawna.pl, Jest zgoda na likwidację Funduszu Kościelnego: Odpis podatkowy od stycznia 2015 roku, http://podatki.gazetaprawna.pl/artykuly/742901,jest-zgoda-na-likwidacje-funduszu-koscielnego-odpis-podatkowy-od-stycznia-2015-roku.html (1.12.2013).

${ }^{41}$ A. Zwoliński, Nie ma zgody między rzadem a Kościotem. Księża chca jeszcze 1,5 mld ztotych, http:/www.money.pl/gospodarka/raporty/artykul/nie;ma;zgody;miedzy;rzadem;a;kosciolem;ksie za;chca;jeszcze;1;5;mld;zlotych,15,0,1594895.html (1.12.2013).

${ }^{42}$ A. Zwoliński, Zamiast likwidacji Funduszu Kościelnego, podwyżki dla księży, http://www. money.pl/gospodarka/raporty/artykul/zamiast-likwidacji-funduszu-koscielnego-,157,0,1642909. html (26.10.2014).

43 D. Subbotko, W 2013 r. dotacje tylko dla czasopism kulturalnych?, http://wyborcza.pl/1,75475,12900681,W_2013_r__dotacje_tylko_dla_czasopism_kulturalnych_.html (1.12.2013).

${ }^{44}$ Wyborcza.pl, Ministerstwo Kultury dofinansowato czasopisma. Czy pominięte periodyki upadnq?, http://wyborcza.p1/1,75475,15445682,Ministerstwo_Kultury_dofinansowalo_czasopisma_ Czy.html (1.12.2013). 


\section{CONCLUSIONS}

In this paper, an informal model of Politicians' and Social Leaders' mutual relations has been proposed, which offers to unify many aspects of observed behavior under explanatory principles stemming from public choice theory.

Much work remains to be done. This model focused on the behavior of Leaders who generally last longer than Politicians and whose source of benefits is not so much the success of a particular Politician, but the existence of competition among Politicians itself. It seems that only a source of income truly independent of government enables a Leader to be more independent in their judgment of Politicians. In other words, the more a Leader is economically self-subsistent, the more he or she should be likely to direct political activities of its followers precisely. A hypothesis that the more inherently bound interests between a Leader and a Politician, the more unambiguous persuasion, also remain to be tested. In this and other contexts, the neglected issue of ideology as constraint on actions would have to be reintroduced.

Formalization of the model and developing diverse forms of collecting empirical data, including quantitative and experimental methods, seem obviously ahead. Strategic behavior of all actors, whose results depend on decisions of others, calls surely for a game theoretic analysis. Further research in uncovering true meanings of Politician's and Leaders' communication and behavior may well turn out fruitful for those engaged with their scientific work. And it may well turn out significant for those engaged with their affairs as citizens, media recipients and religious believers.

\section{BIBLIOGRAPHY}

Baron D.P., Electoral Competition with Informed and Uninformed Voters, „American Political Science Review", Vol. 88, No. 1/1994, http://dx.doi.org/10.2307/2944880.

DellaVigna S., Kaplan E., The Fox Nerws Effect: Media Bias and Voting, „The Quarterly Journal of Economics", Vol. 122, No. 3/2007, http://dx.doi.org/10.1162/ qjec.122.3.1187.

Downs A., An Economic Theory of Democracy, Harper \& Row, New York 1957.

Downs A., An Economic Theory of Political Action in a Democracy, ,Journal of Political Economy", Vol. 65, No. 2/1957, http://dx.doi.org/10.1086/257897.

Dunleavy P., Ward H., Exogenous Voter Preferences and Parties with State Power: Some Internal Problems of Economic Theories of Party Competition, „British Journal of Political Science", Vol. 11/1981, http://dx.doi.org/10.1017/S0007123400002684. 
Dziennik.pl, 7 mln zt za rzqdowy spot. „Niech PO wpisze to w koszty kampanii”, http:// wiadomosci.dziennik.pl/polityka/artykuly/456827,pis-o-rzadowym-spocie-za-7-mln-zl-niech-po-wpisze-to-w-koszty-kampanii.html (01.12.2013).

Eagly A.H., Wood W., Chaiken Sh., Causal inferences about communicators and their effect on opinion change, "Journal of Personality and Social Psychology", Vol. 36, 4/1978, http://dx.doi.org/10.1037/0022-3514.36.4.424.

Episkopat.pl, Odpowiedzialność za dobro wspólne, http://episkopat.pl/dokumenty/listy_ pasterskie/4486.1,Odpowiedzialnosc_za_dobro_wspolne.html (01.12.2013).

Fonda.pl, Prezydent Komorowski: Kościót to ważny element spoteczeństwa, http:// www.fronda.pl/a/prezydent-komorowski-kosciol-to-wazny-element-spoleczenstwa,31237.html (01.12.2013).

Gazeta.pl, PiS ptacito radiu Skowrońskiego i Lux Veritatis, http://www.tokfm.pl/ Tokfm/1,103087,14085943,PiS_placilo_radiu_Skowronskiego_i_Lux_Veritatis_ Kaminski_.html (01.12.2013).

GazetaPrawna.pl, Jest zgoda na likwidacje Funduszu Kościelnego: Odpis podatkowy od stycznia 2015 roku, http://podatki.gazetaprawna.pl/artykuly/742901,jest-zgoda-na-likwidacje-funduszu-koscielnego-odpis-podatkowy-od-stycznia-2015-roku. html (01.12.2013).

Gill A., The Political Origins of Religious Liberty, Cambridge University Press 2008.

Górny G., Czego uczy nas Jerzy Owsiak, http://www.wsieci.pl/czego-uczy-nas-jerzy-owsiak-pnews-245.html (30.11.2013).

Grofman B., Introduction, [in:] B. Grofman (ed.), Information, Participation, and Choice: An Economic Theory of Democracy in Perspective, University of Michigan Press 1995.

Grofman B., Norrander B., Efficient use of reference group cues in a single dimension, „Public Choice”, No. 64/1990, http://dx.doi.org/10.1007/BF00124367.

Grossman G.M., Helpman E., Competing for Endorsements, „The American Economic Review", Vol. 89, No. 3/1999, http://dx.doi.org/10.1257/aer.89.3.501.

Grossman G.M., Helpman E., Protection for Sale, „The American Economic Review”, Vol. 84, No. 4/1994.

Hovland C.I., Janis I.L., Kelley H.H., Communication and persuasion: psychological studies of opinion change, Greenwood Press 1953.

Jackson J.E., Electoral Competition with Endogenous Voter Preferences, Unpublished paper prepared for the Annual Meeting of the Midwest Political Science Association, Chicago, April 19, 1996.

Jelen T.D., Notes for a Theory of Clergy as Political Leaders, [in:] S.E.S. Crawford, L.R. Olson (eds.), Christian Clergy in American Politics, JHU Press 2003.

Kamiński W., Rzqdowe miliony dla „Wyborczej, http://gpcodziennie.p1/24252-rzadowe-miliony-dla-wyborczej.html (01.12.2013).

Klasnja M., Why Do Malfeasant Politicians Maintain Political Support? Testing the „Uninformed Voter" Argument, Unpublished Draft, August 2011. 
Lepczyński K., Dtuga droga Skowrońskiego. Od radiowej grwiazdy do „konferansjera PiS”, http://www.tokfm.p1/Tokfm/1,103088,14088108,Dluga_droga_Skowronskiego_ Od_radiowej_gwiazdy_do.html (29.11.2013).

Michalak T., Ekonomiczna teoria demokracji Anthony'ego Downsa, [in:] J. Wilkin (ed.), Teoria wyboru publicznego, Wydawnictwo Scholar, Warszawa 2005.

Nicita A., Pagano U., Incomplete contracts and institutions, [in:] J.G. Backhaus (ed.), The Elgar Companion to Law and Economics, Edward Elgar 2005.

Nowakowska A., Wielowieyska D., Jak PiS i PO wydaja miliony z budżetu, http://wyborcza.pl/politykaekstra/1,133134,14083575,Jak_PiS_i_PO_wydaja_miliony_z_ budzetu.html (30.11.2013).

PAP, Będzie likwidacja Funduszu Kościelnego?, http://www.tvp.info/5463535/informacje/polska/bedzie-likwidacja-funduszu-koscielnego/ (01.12.2013).

Petrova M., Political Economy of Media Capture, [in:] R. Islam (ed.), Information and Public Choice. From Media Markets to Policy Making, The World Bank, Washington 2008.

Popkin S.L., The Reasoning Voter: Communication and Persuasion in Presidential Campaigns, University of Chicago Press 1994.

Smith A., Badania nad natura i przyczynami bogactwa narodów, PWN, Warszawa 1954.

Sole-Olle A., Sorribas-Navarro P., Do Corruption Scandals Erode Trust in Government? Evidence from a Matched Sample of Local Governments, Unpublished paper prepared for the CESifo Area Conference on Public Sector Economics, Munich, 2426 April 2014.

Subbotko D., W 2013 r. dotacje tylko dla czasopism kulturalnych?, http://wyborcza. pl/1,75475,12900681,W_2013_r__dotacje_tylko_dla_czasopism_kulturalnych_. html (01.12.2013).

TVP.info, Kto atakuje Kościót, ten atakuje Polskę, http://tvp.info/informacje/polska/kto-atakuje-kosciol-ten-atakuje-polske/6765592 (01.12.2013).

TVP.info, Orędzie prymasa Glempa na Bö̇e Narodzenie, http://tvp.info/magazyn/ kartka-z-kalendarza/oredzie-prymasa-glempa-na-boze-narodzenie/9856914 (30.11.2013).

Wegenast T., Uninformed Voters for Sale: Electoral Competition, Information and Interest Groups in the US, „Kyklos”, Vol. 63, No. 2/2010, http://dx.doi.org/10.1111/ j.1467-6435.2010.00473.x.

Woolfolk M., Sermons Aren't Explicitly Political: Political Cue-Giving in Sermons by U.S. Christian Clergy, Unpublished Working Paper May $9^{\text {th }} 2013$.

wPolityce.pl, Woodstock - festiwal konserwujacy III RP, http://wpolityce.pl/ wydarzenia/32624-woodstock-festiwal-konserwujacy-iii-rp-goscmi-owsiaka-beda-min-prezydent-komorowski-redaktor-paradowska-oraz-bp-pieronek (29.11.2013).

Wyborcza.pl, Ministerstwo Kultury dofinansowato czasopisma. Czy pominięte periodyki upadna?, http://wyborcza.pl/1,75475,15445682,Ministerstwo_Kultury_dofinansowalo_czasopisma_Czy.html (01.12.2013). 
Wyborcza.pl, Prezydent zagrat z Owsiakiem już w sobote, http://wyborcza. pl/1,76842,13188298,Prezydent_zagral_z_Owsiakiem _juz _w_sobote.html (30.11.2013).

Youtube.pl, Chtodnym okiem - Bronistaw Wildstein o reklamie w Gazecie Wyborczej, http://www.youtube.com/watch?v=w3uuGoqeaf0 (01.12.2013).

Zaller J.R., The Nature and Origins of Mass Opinion, Cambridge University Press 1992.

Zwoliński A., Fundusz Kościelny to nic. Zobacz, ile kosztuje nas konkordat, http://www. money.pl/gospodarka/raporty/artykul/fundusz;koscielny;to;nic;zobacz;ile;kosztuje; nas;konkordat,17,0,1046545.html (01.12.2013).

Zwoliński A., Nie ma zgody między rządem a Kościotem. Księża chca jeszcze 1,5 mld ztotych, http://www.money.pl/gospodarka/raporty/artykul/nie;ma;zgody;mied zy;rzadem;a;kosciolem;ksieza;chca;jeszcze;1;5;mld;zlotych,15,0,1594895.html (01.12.2013).

Zwoliński A., Zamiast likwidacji Funduszu Kościelnego, podwyżki dla księży, http:// www.money.pl/gospodarka/raporty/artykul/zamiast-likwidacji-funduszu-koscielnego-,157,0,1642909.html (26.10.2014). 
